University of Nebraska - Lincoln

DigitalCommons@University of Nebraska - Lincoln

Faculty Publications, UNL Libraries

Libraries at University of Nebraska-Lincoln

$3-2012$

Discovering, Promoting and Maintaining Emerging Technologies. A Report of the LITA Emerging Technologies Interest Group Meeting, American Library Association Annual Meeting, New Orleans, June 2011

Kiyomi D. Deards

University of Nebraska-Lincoln, kdeards2@unl.edu

Follow this and additional works at: http://digitalcommons.unl.edu/libraryscience

Deards, Kiyomi D., "Discovering, Promoting and Maintaining Emerging Technologies. A Report of the LITA Emerging Technologies Interest Group Meeting, American Library Association Annual Meeting, New Orleans, June 2011" (2012). Faculty Publications, UNL Libraries. 314.

http://digitalcommons.unl.edu/libraryscience/314

This Article is brought to you for free and open access by the Libraries at University of Nebraska-Lincoln at DigitalCommons@University of Nebraska - Lincoln. It has been accepted for inclusion in Faculty Publications, UNL Libraries by an authorized administrator of DigitalCommons@University of Nebraska - Lincoln. 
Published in Technical Services Quarterly 29:2 (2012), pp. 150-155;

doi: 10.1080/07317131.2012.650952

Copyright (C) 2012 Taylor and Francis/Routledge. Used by permission.

Published online March 20, 2012.

\title{
Discovering, Promoting and Maintaining Emerging Technologies. A Report of the LITA Emerging Technologies Interest Group Meeting, American Library Association Annual Meeting, New Orleans, June 2011
}

\author{
Kiyomi D. Deards \\ University of Nebraska - Lincoln, Lincoln, NE
}

The LITA ETIG (Library \& Information Technology Association Emerging 
Technologies Interest Group) was hosted by Patrick Griffis of the University of Nevada, Las Vegas. Griffis reminded attendees that the LITA Emerging Technology Interest Group exists as a forum to share ideas about, and discuss the use of, emerging technologies in libraries.

Conversation then turned to the ETIG sponsored, and highly attended, "Lost in Translation" panel discussion, which was held the previous morning. The panel focused on the question of how libraries are addressing emerging technology issues and consisted of four individuals ranging from administrators to technical services staff who discussed the obstacles to implementation, communication issues, and how organizations are dealing with, assessing, and implementing emerging technologies. Key issues revealed in the discussion were that emerging technology implementation takes staff time and costs money both for implementation and ongoing maintenance. In addition it's important that there is good communication between those who are charged with completing technical tasks and those who are requesting projects. For example, if the size of a project increases, it is important that administrators are made aware of the increased staffing needs due to increased staff time requirements and/or increased costs of equipment so that they can prioritize and decide whether to add staff and funding, or alter timelines or workloads, to take new additions to the project into account.

\section{How Is Technology Used?}

Technology is used to promote, teach, work, and play. When emerging technologies are pursued, it is important to balance actual use with new tech toys. Dry erase boards, with frames to scan as people write, are popular; however, they are more often used for the boards themselves than the technology attached to them. At times the iPod/iPhone is more useful than an iPad. Smaller is not always better as it can be difficult to take notes on miniature devices. Screen size preferences may also be an issue in the future, for example, double monitors for catalogers and others working with multiple programs or big data sets can be a huge plus. Miniature plug and play computers may be the solution, allowing people to utilize large monitors and keyboards when desired but with the transportability of a smart phone. A current example of this technology is the ATRIX phone which boasts a dual core processor and can be docked to already existing computers, GPS docks, and home entertainment systems. Related mobile entertainment devices and programs are the Slingbox, Apple TV, Roku, Netgear Push2TV, Playstation's Playstation Portable with Remote Play (like remote desktop but for the gaming console), and MiFi. Sometimes low tech is just as impressive as high tech, such as mini wireless Bluetooth keyboard for smartphones. People want to type and have an external mouse that doesn't require users to use the phone to switch between apps as is currently required. 


\section{What Are Emerging Technologies?}

The point was made that just because what someone is doing with something is innovative does not make it an emerging technology. We should ask ourselves: What technologies are being used by our patrons? (Android vs. iPhone vs. iPad vs. Samsung, etc.) What are today's emerging technologies and how can libraries take advantage of them? When should new technologies be adopted? Are these technologies relevant to our users or are we just using them because we can? When should we get rid of them? Do we just coopt emerging technologies from other industries or develop our own, for example, mobile technologies? One difficulty can be getting library staff on board with emerging technology. Some people are really involved, others just don't seem to get it, and there are those who don't have a cell phone or use e-mail.

\section{Issues to Consider When Dealing with Emerging Technologies}

- Are items staff-use only or can they be checked out?

- How can this service be funded and will it matter to our patrons?

- What will not be done so new things can be funded and supplied?

- What will benefit users the most 10 years from now?

- How will items be physically and digitally maintained?

- What devices will be purchased and supported? Gaming Consoles, iPads, e-Book Readers, etc.?

- Legal and policy issues, such as, how are items or programs licensed?

- When there is a problem with an item is it the operator, the application, or the platform?

- It is hard to help someone on a completely different operating system.

- It is impossible to test the usability of a vendor app without a device to install them on.

- What is popular and frequently used in one area may not be in another area due to demographics and carrier availability. Find out what people are using before purchasing, for example, at one institution only two students at new student orientation did not have iPhones.

- Check the wireless capabilities in buildings and extended workplaces; if coverage is poor people will only be frustrated trying to use mobile technologies.

- Does the technology require users to sign in multiple times? Is the value of the service higher than the irritation of patrons at having to sign in multiple times? 


\section{Barriers to Use and Experimentation with Emerging Technologies}

- Lack of knowledge of new technologies.

- Budget shortfalls often mean cuts in technology not upgrades, and cuts in personnel.

- New executable files and updates can only be installed by technical services. Default screen capture programs are clunky and frustrating to use even for the tech savvy.

- Relying on IT for everything means IT is always very busy keeping things up-to-date.

\section{Discovering Emerging Technologies}

Emerging Technologies can be investigated by doing things such as attending the International Consumer Electronics Show in Las Vegas (http:// www.ces web.org/). This is where industry goes to spot emerging technologies; librarians should be there too. Libraries can pursue industry partnerships. Many library problems are trivial to industry which has the money and human resources to solve problems quickly and efficiently. Librarians also need to persuade more technology vendors to come to library meetings/conventions. Lack of communication and timing of conventions are possible barriers to this. When individuals move on to other jobs or retire, their positions could be repurposed; emerging technologies take staff time to pursue and implement. There could be a concerted effort to create more multi-library and library consortium funded programmer positions. Librarians can follow active technophiles using social media to discover what's hot and what's not. We need to think ahead instead of constantly being in a state of, "Oh No! We're behind, AHHHH!"

\section{Promoting Emerging Technologies}

Suggested methods to distribute ideas about current and future emerging technologies included, find out what people at a given institution read most (e-mail, blogs, message boards, bulletin boards, mailing lists, Twitter, etc.). Websites often have a button that allows individuals to send popular articles to others by e-mail. Analytics can be used to see how people are browsing library websites, allowing people to prioritize their efforts. Many workplaces have brown bag lunches at which employees can present and spread their ideas. Libraries can host "How to use your [insert type of smart phone]" or "Learn how to talk to your grandchildren with Skype" programs. One-day technology conferences for all campus or city employees would give individuals the freedom to drop by and experiment when it was most convenient for them. Short-term trials can be used to effectively identify what works and 
what doesn't for less risk, saving money and increasing the success of fullscale program launches. Permanent technology petting zoos allow employees to try out and get a feel for new technologies. Alternately, a "What I got for Christmas (Technology) Party" is a cheap but effective alternative. Wii bowling has been used as a scholarship fundraiser. Events such as these can be viewed as an opportunity to addict people to technology.

Augmented Reality was the hot topic of the meeting. With augmented reality applications such as Layer Browse, people could stand in the stacks looking for a specific call number. It could be used to create multi-lingual library signage and maps, self-guided tours (to see a floor click on it to get more information), enhance special collections exhibits, and provide virtual tours of delicate artifacts. Tours with added layers of information, accessible depending on an individual's interest, could be built such as information about important buildings on campus, lost architecture, and plants and trees in botanical gardens. It is possible to purchase cameras with geotagging to simplify the creation of such tours. There has been great progress with this technology but the group felt that it had not yet emerged, as geolocation standards are not very accurate at this time, for example, many people would use their smart phone to guide them on an augmented reality tour but the geotagging on these devices is only accurate to within approximately 60 meters on average. Another barrier is download speeds. High media content will demand higher bandwidth and faster download speeds for augmented reality to take off.

Distance education is increasingly becoming a fact of life. Library materials are being mailed all over the world. How do shipping costs compare to ebook costs (remembering that Internet access might be unreliable depending on where students are located). A suggestion for incorporating e-book materials in distance education included a one-year trial in which purchasing would be e-preferred to track what costs less, e-books or shipping. Librarians were also advised to remember that not all books are available in e-book format and some titles would only be available for purchase in print.

Interlibrary Loan (ILL) may be one area where emerging technologies have the potential to be very useful. Add-ons are currently available to allow workers in ILL to compare costs of buying versus borrowing, and to check open source repositories to see if the item is available for free, thus allowing libraries to make the most economical choice. But the fact remains that in spite of these efficiencies ILL can only be automated so much; there is still a need for the human component. Many libraries put lower level people in charge of ILL and don't provide staff development for workers in ILL, making it hard for workers not to fall behind in professional development. It was felt that it is better for the person in charge of ILL to be in a management or librarian faculty position. Questions being asked include: What is in the public domain? What are the rules on digitizing items in the 
public domain? Can we share digitization of public domain works with an unlimited number of people?

Mobile options include developing ILL mobile applications, and mobile optimized websites are a necessity. Content ideas include hours, study area reservations, ask a librarian, and links to videos (tutorials, special events, promos). Each mobile website needs to be optimized for several different browsers. There is no standard mobile browser. Suggestions include having gamers develop our mobile websites or applications and add a simple but fun game. Working with campus or city IT departments to create a single mobile application which includes the library is theorized to increase downloads as the applications would be more relevant to individuals. It's important not to focus on one device. Applications need to be marketed where the users shop: iTunes, Android Market Place, etc. An example of a successful mobile application is Stack Map in combination with radio-frequency identification (RFID) tags it can be used to tell if a book is misplaced and provide interactive maps of the library.

Other topics discussed:

- AIs (Artificial Intelligences) are not mainstream yet; they give unreliable answers. It takes a large amount of time to develop a true AI that can answer the random and idiomatic questions reference librarians encounter every day.

- Barcoding and RFID tagging: can we add these quickly and cheaply or will cost and size of the collection make it difficult for large collections to be processed?

- Communication issues: using mobile devices equipped with programs and applications such as AIM, Gmail, GChat, and Microsoft Certified to be more available to colleagues and patrons when on the go.

- Develop format documentation to aid people when helping patrons.

- If digital only formats were purchased, what would be left behind?

- Mobile check-out with open source barcode technology (demagnetization is a challenge).

- Tracking usage statistics to determine staffing time and materials budget priorities for reference and circulation desk staffing versus oncall status, and print versus electronic formats, etc. 